\title{
Moralne aspekty homoseksualizmu w świetle wypowiedzi Magisterium Kościoła po Soborze Watykańskim II
}

\author{
Moral Aspects of Homosexuality in Light of the Ecclesiastical Magisterium \\ after the Second Vatican Council
}

\author{
MACIEJ OLCZYK \\ Uniwersytet im. Adama Mickiewicza w Poznaniu \\ donmatti@amu.edu.pl, ORCID: 0000-0002-3122-8230
}

\begin{abstract}
Streszczenie: Artykuł podejmuje analizę moralnych aspektów homoseksualizmu w świetle posoborowego nauczania Kościoła katolickiego. Refleksja składa się z dwóch części. Pierwsza nawiązuje do zasadniczych tez antropologii biblijnej, będącej fundamentem katolickiej etyki seksualnej. Teologia stworzenia ukazana w Księdze Rodzaju stanowi dla chrześcijan podstawę do adekwatnego zrozumienia problemów związanych z homoseksualizmem. Dołącza do niej refleksja rozumowa, analizująca cielesno-duchową naturę osoby ludzkiej, będącą źródłem praw i obowiązków wyrażonych w prawie naturalnym. Idąc tym tropem, druga część artykułu koncentruje się na moralnej ocenie homoseksualizmu i formułuje wynikające z tej oceny implikacje dla wspólnoty kościelnej i społeczeństwa. W świetle orędzia biblijnego i nauki Kościoła zjawisko homoseksualizmu jawi się jako przeżywanie ludzkiej seksualności wbrew mądrości i miłości Stwórcy. W ocenie moralnej istotne jest jednak rozróżnienie pomiędzy homoseksualną skłonnością a czynami. Szanując godność każdej osoby, Kościół podkreśla, że żadna skłonność nie determinuje bezwzględnie ludzkich wyborów moralnych. Dlatego zachęca osoby o skłonnościach homoseksualnych, aby w przyjaźni z Chrystusem podjęły drogę pełnienia woli Bożej we wspólnocie wiary.
\end{abstract}

Słowa kluczowe: homoseksualizm, małżeństwo, ocena moralna, związki partnerskie

\begin{abstract}
The article analyzes the moral aspects of homosexuality in light of the post-conciliar (Vaticanum Secundum) teaching of the Catholic Church. Reflection consists of two main parts. The first part refers to the fundamental theses of biblical anthropology as the foundation of Catholic sexual ethics. The theology of creation presented in the Book of Genesis is the basis for Christians to adequately understand the problems related to homosexuality. It is joined by a rational reflection analyzing the nature of the human person, which is the source of rights and obligations expressed in natural law. Following this path, the second part of the article focuses on the moral evaluation of homosexuality and formulates the implications of this evaluation for the ecclesiastic community and society. In light of the biblical message and the teaching of the Church, the phenomenon of homosexuality presents as a realization of human sexuality contrary to the wisdom and love of the Creator. In moral judgment, however, it is important to distinguish between homosexual inclination and actions. While respecting the dignity of each person, the Church emphasizes that no inclination directly determines one's moral choices. For this reason, the Magisterium encourages people with homosexual inclinations to take the path of God's will in spiritual friendship with Christ in the community of faith.
\end{abstract}

Keywords: homosexuality, marriage, moral evaluation, partnerships 
Ludzka płciowość stanowi egzystencjalnie doniosłą i bardzo złożoną rzeczywistość. Może być rozpatrywana z różnych perspektyw. Jej naturę oraz znaczenie próbują wyjaśnić religie, filozofie, nauki o człowieku. W XX w. płeć została wydobyta ze sfery intymnej i trafiła na sztandary grup politycznych inspirujących zmiany społeczno-obyczajowe. Wyraźnym przykładem tych procesów jest aktywność organizacji i ruchów promujących równouprawnienie tzw. mniejszości seksualnych. Wśród ich inicjatyw szczególne miejsce zajmuje kampania na rzecz zmiany w postrzeganiu homoseksualizmu przez społeczeństwo ${ }^{1}$.

Celem tej kampanii, rozłożonej na poszczególne etapy, było najpierw przezwyciężenie dyskryminujących praktyk społecznych, jakich doświadczały osoby o skłonnościach homoseksualnych. Postulowane równouprawnienie prowadziło do poszerzania zakresu swobód nie tylko w obszarze obyczajowym, ale także w sferze prawodawstwa państwowego i międzynarodowego. Silne i sprawnie działające organizacje, reprezentujące żądania osób homoseksualnych, doprowadziły do zmian w postrzeganiu homoseksualizmu w psychologii i psychiatrii. Aktywna reprezentacja interesów środowiska homoseksualnego w świecie polityki wymogła na parlamentach wielu państw legalizację związków między osobami tej samej płci, dając im także w wielu przypadkach możliwość adopcji dzieci. Również niektóre wyznania chrześcijańskie zaakceptowały homoseksualny styl życia i zaaprobowały sprzeczne z orędziem biblijnym postulaty mniejszości seksualnych ${ }^{2}$. Tendencje te przenikały i wciąż przenikają także do katolicyzmu, powodując zamieszanie w odbiorze nauczania Kościoła w tej dziedzinie.

Kościół katolicki analizuje te procesy z zatroskaniem i z nadzieją, oświetlając współczesne problemy mądrością Bożego słowa. Nowe otwarcie na dialog ze światem, zapoczątkowane wraz z Soborem Watykańskim II, spotkało się jednak w obszarze etyki seksualnej z falą kontestacji i sprzeciwu wobec moralności chrześcijańskiej, która w znacznej mierze kształtowała dotychczasową matrycę obyczajową zachodniego świata. Instytucje takie jak małżeństwo mężczyzny i kobiety oraz trwała rodzina wychowująca dzieci zostały poddane krytyce ze strony nowych ideologii, interpretujących te wspólnoty jako środowiska zniewalające i opresyjne. Apoteoza wolności pojmowanej na sposób indywidualistyczny prowadziła do odrzucania norm społecznych i zakwestionowania dotychczasowych kanonów dobra i zła moralnego. Odbijało się to również na podejściu do religii, zwłaszcza do katolicyzmu, który w swoim przesłaniu etycznym stoi na straży Bożego ładu, przypomina powołanie mężczyzny i kobiety, broni wartości małżeństwa i podkreśla rolę rodziny. W obliczu narastających napięć i nieporozumień związanych z niewłaściwym rozumie-

1 W niniejszym artykule przez homoseksualizm rozumie się, zgodnie z określeniem obecnym w Katechizmie Kościoła Katolickiego (2357), ,relacje między mężczyznami lub kobietami odczuwającymi pociąg płciowy, wyłączny lub dominujący, do osób tej samej płci”.

2 Niektóre liberalnie zorientowane Kościoły anglikańskie, prezbiteriańskie i metodystyczne uznały biblijne nauczanie o homoseksualizmie za uwarunkowane kulturowo. Por. Augustyn, „Homoseksualizm”, 13. 
niem lub celowym dyskredytowaniem katolickiej etyki seksualnej konieczne stawało się podejmowanie nowych prób uzasadnienia stanowiska Kościoła. Kolejni papieże i watykańskie dykasterie wielokrotnie zabierały głos na tematy dotyczące istoty i znaczenia ludzkiej płciowości, odnosząc się także wprost do zagadnienia homoseksualizmu ${ }^{3}$. Warto zatem powrócić do tych wypowiedzi i wydobyć z nich podstawowe treści, które pomogłyby zwłaszcza osobom wierzącym w budowaniu argumentacji potrzebnej we współczesnej debacie na tematy związane z ludzką płciowością, szczególnie w kontekście powracających pytań o skłonności i zachowania homoseksualne. Celem artykułu jest zatem ukazanie moralnych aspektów homoseksualizmu oraz argumentacji, jaka przy jego ocenie etycznej pojawia się w posoborowych wypowiedziach Magisterium Kościoła katolickiego.

Zaproponowana refleksja składa się z dwóch zasadniczych części. Pierwsza dotyczy fundamentu katolickiej etyki seksualnej, czyli osadzonej w Objawieniu biblijnym antropologii teologicznej. Zamysł Boży wobec mężczyzny i kobiety objawiony w Piśmie Świętym jest punktem wyjścia dla refleksji moralnej. W jego świetle możliwe jest poprawne rozpatrywanie szczegółowych problemów etycznych dotyczących tożsamości seksualnej, miłości, małżeństwa czy rodziny. W polu wyznaczonym współrzędnymi Bożego zamysłu zostało zatem umieszczone - zgodnie ze wskazaniami Magisterium Kościoła ${ }^{4}$ - także zjawisko homoseksualizmu. W ten sposób możemy je ocenić w perspektywie teologicznej, czyli zgodnie z tym, jak ten fenomen interpretuje Boże słowo i nauczanie Kościoła katolickiego. Druga część artykułu koncentruje się na moralnej ocenie homoseksualizmu i formułuje wynikające $z$ tej oceny konsekwencje dla wspólnoty kościelnej i społeczeństwa.

\section{Antropologia biblijna jako fundament adekwatnej oceny homoseksualizmu}

Chrześcijaństwo głosi światu Ewangelię, w której człowiek może odnaleźć prawdę o Bogu i o sobie samym. Jaśnieje ona w Bożym słowie spisanym na kartach Biblii, a ostatecznie została objawiona w Słowie, które stało się ciałem i zamieszkało między nami (por. J 1,14). Jeśli zatem człowiek chce odnaleźć prawdę o sobie samym i jednocześnie zrozumieć różnicę pomiędzy dobrem i złem moralnym, musi ze swymi pytaniami zwrócić się do swego Stwórcy i Odkupiciela 5 .

3 Wykaz najważniejszych dokumentów Kościoła katolickiego na ten temat, zob. bibliografia na końcu artykułu.

4 Por. Kongregacja Nauki Wiary, Homosexualitas problema, nr 6.

5 Por. Jan Paweł II, Redemptor hominis, nr 10. 
Dla pełnego zrozumienia powołania mężczyzny i kobiety, ich wzajemnej relacji intymnej i spoczywających na nich zadan społecznych, jak to przypomniał Jan Paweł II, „punktem wyjścia musi być Boży zamysł wobec człowieka, małżeństwa i rodziny. [...] Z chrześcijańskiego Objawienia wypływa właściwa antropologia oraz sakramentalna wizja małżeństwa i rodziny, zdolna nawiązać dialog z wiedzą uzyska-

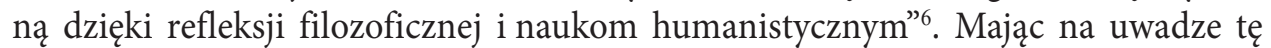
cenną wskazówkę, przyjrzyjmy się zatem zasadniczym wektorom antropologii biblijnej, wyznaczającej właściwe pole rozstrzygania dylematów etyki seksualnej. Do antropologii tej odwołują się wszystkie posoborowe dokumenty Kościoła katolickiego podejmujące zagadnienie homoseksualizmu.

\subsection{Człowiek mężczyzną i kobietą na obraz Boży}

Nauczanie Kościoła katolickiego dotyczące ludzkiej płciowości czy etyki seksualnej zawsze odnosi się do biblijnego opisu stworzenia człowieka przez Boga. Podkreśla się w ten sposób zarówno wagę samego faktu, że człowiek jest istotą stworzoną, a zatem chcianą i umiłowaną przez Boga, jak również wskazuje się na poszczególne elementy opisu stworzenia, wyprowadzając z nich wiążące moralnie treści antropologiczne i teologiczne.

Pismo Święte zawiera dwa, pochodzące z różnych tradycji, opisy stworzenia człowieka. Pierwszy z nich (Rdz 1,26-29) stanowi część poematu na cześć Boga-Stwórcy, jest chronologicznie młodszy, a jego powstanie związane z tradycją kapłańską datuje się na ok. V w. przed Chr. Drugi tekst (Rdz 2,4b-25) pochodzi z tradycji jahwistycznej i powstał ok. X w. przed Chr. ${ }^{7}$ Obydwa teksty stanowią bogate źródło treści antropologicznych, do których odwołują się kościelne dokumenty.

Jedną z kluczowych tez antropologii biblijnej jest prawda o stworzeniu człowieka na obraz Boży. W Księdze Rodzaju znajdujemy najpierw uroczystą zapowiedź wprowadzającą czytelnika w zamiar Boga: „Uczyńmy człowieka na nasz obraz i podobieństwo" (Rdz 1,26). Papieska Komisja Biblijna wyjaśnia, jak poprawnie należałoby przetłumaczyć pojawiający się tu kluczowy zwrot „na obraz i podobieństwo”. Aby jak najlepiej oddać oryginalny zapis, wyrażenie to $\mathrm{w}$ języku polskim powinno brzmieć: „na obraz według podobieństwa”, a w tłumaczeniu dynamicznym mogłoby zostać wyrażone słowami: „na obraz przypominający”. Sformułowanie to ukazuje z jednej strony, że człowiek nosi w sobie coś boskiego, ale jednocześnie uświadamia, że obraz (człowiek) nie jest tym samym, co oryginał (Bóg). Jest prawdopodobne, że „za pomocą tego terminu autor $\mathrm{Rdz} 1$ chciał podkreślić uprzywilejowane podobieństwo

Jan Paweł II, „Ojcostwo i macierzyństwo”, nr 6.

Por. Synowiec, Na początku, 9-10. 
między człowiekiem a Stwórcą, które stanowi pierwotną podstawę historycznego dialogu między dwoma podmiotami"8.

Rdz 1,27 stwierdza dokonanie zapowiedzianego wcześniej aktu stwórczego: „Stworzył więc Bóg człowieka na swój obraz, na obraz Boży go stworzył: stworzył mężczyznę i niewiastę". Myśliciele chrześcijańscy od czasów patrystycznych zastanawiali się, w czym konkretnie wyraża się wspomniany obraz Boga w człowieku9 Upatrywali go w duchowości, rozumności, świętości, wolności, zdolności panowania, umiejętności kochania, predyspozycji do tworzenia wspólnoty. Podkreślano zasadniczo właściwości natury duchowej. Wnioskowano, że skoro Bóg jest duchem, to podobieństwo do Niego powinno mieć charakter duchowy. Egzegeci sugerują tu jednak konieczność poszerzenia perspektywy: Księga Rodzaju nie pozostawia cienia wątpliwości, że cały człowiek jest obrazem Boga, a zatem „obraz Boży w człowieku dotyczy sfery duchowej oraz cielesnej. Co więcej, [...] słowa «stworzył mężczyzną i niewiastą» wyraźnie nasuwa myśl o cielesności, wskazuje bowiem na zróżnicowanie płci jako nieusuwalną kondycję i sedno człowieczeństwa"10. Pismo Święte sugeruje zatem, że obraz Boży w człowieku ma jakiś tajemniczy związek z męskością i kobiecością, wyrażającymi się miedzy innymi poprzez ciało. W konsekwencji, jeśli ciało ludzkie uczestniczy w godności Bożego obrazu ${ }^{11}$, a według zamysłu Bożego jest zróżnicowane płciowo jako męskie i kobiece, to również sama płciowość w jej dwoistości nie tylko jest chciana przez Boga właśnie jako taka, ale komunikuje nam coś o Bogu. Choć Bóg rzeczywiście jest istotą duchową, to jednak objawia prawdę o sobie za pośrednictwem swego obrazu - człowieka - będącego z natury istotą cielesno-duchową i płciową ${ }^{12}$.

Co zatem o Bogu komunikuje Jego obraz, czyli zróżnicowany płciowo człowiek? Analizując Rdz 1, zauważamy, że męskość i kobiecość pozwalają zamanifestować się jednemu $\mathrm{z}$ fundamentalnych przymiotów Bożych, jakim jest życiodajność. Bóg powołuje do istnienia świat, a istotom żywym udziela życia. Opatrzność Boża podtrzymuje byty w istnieniu, stąd Księga Mądrości nazywa Boga miłośnikiem życia (por. Mdr 11,26). Zgodnie z wolą Bożą świat roślin i zwierząt charakteryzuje się wpisanym w ich naturę dynamizmem rozrodczym. Jedynie w stosunku do ludzi, szanując ich osobową naturę, Bóg kieruje polecenie powiązane z błogosławieństwem, aby byli płodni i rozmnażali się (por. Rdz 1,28). Henryk Witczyk zauważa, że „życie będące jednym z aspektów «obrazu Bożego» w człowieku - winno być chronione i otaczane wszelką możliwą opieką i obroną. Uobecnia ono w człowieku coś z życia samego Boga [...] pochodzi od Boga jako Jego dar, ale jest także ukierunkowane na

\footnotetext{
Papieska Komisja Biblijna, Czym jest człowiek (Ps 8,5), nr 46.

Por. Mondin, L’uomo secondo il disegno di Dio, 156-161; Czyżewski, „«Uczyńmy człowieka na nasz obraz, podobnego nam» (Rdz 1,26)", 113-126.

10 Chrostowski, „Ludzka cielesność”, 10.

11 Por. Katechizm Kościoła Katolickiego, nr 364.

12 Por. Papieska Rada ds. Rodziny, Ludzka płciowość, nr 10.
} 
uczestnictwo w Jego miłości, chwale i wieczności”13. Zagadnienie to podjął od strony etycznej Jan Paweł II w encyklice Evangelium vitae. Analizując polecenie Boże dane pierwszym rodzicom $(\mathrm{Rdz} 1,28)$, papież podkreśla zadanie obrony, umacniania, czczenia i kochania życia, będące wyrazem obrazu Bożego w człowieku ${ }^{14}$. Dodaje również, że szczególnym przejawem udziału człowieka w panowaniu Boga jest troska o życie prawdziwie ludzkie. „Najwznioślejszym przejawem tej odpowiedzialności jest przekazywanie życia przez akt zrodzenia, dokonany przez mężczyznę i kobietę w małżeństwie"15.

Wynika z tego stwierdzenia, że tylko małżeństwo mężczyzny i kobiety może zagwarantować najlepsze warunki do poczęcia i dojrzewania życia prawdziwie ludzkiego. Przez ową prawdziwość w sensie teologicznym rozumieć należy, że człowiek jest osobą o cielesno-duchowej naturze oraz że prokreacja, będąc kontynuacją stworzenia, rodzi nie tylko człowieczeństwo, ale i wpisuje w ludzką osobę obraz Boży ${ }^{16}$. Ten obraz maluje się na twarzy dziecka tym wyraźniej, im bardziej może ono doświadczyć miłości swoich rodziców: ojca i matki, którzy są dla niego w pewnym sensie widzialnym obliczem Boga, zapośredniczonym w ich męskości i kobiecości. Tak spełnia się proces, o którym Jan Paweł II napisze wymownie: „,w biologię rodzenia wpisana jest genealogia osoby" ${ }^{17}$. Zróżnicowanie płciowe ma w tych relacjach niebagatelne znaczenie ${ }^{18}$.

Męskość i kobiecość stanowią chciane przez Boga i równe w godności dwa sposoby udziału człowieka w Boskim Bycie. Ukierunkowani dzięki różnicy płciowej na zjednoczenie i życiodajną płodność, mężczyzna i kobieta, połączeni związkiem małżeńskim, mają udział w stwórczej miłości Boga ${ }^{19}$. Szczególnym wyrazem życiodajności jest intymne zjednoczenie mężczyzny i kobiety. Ukazuje ono, że „człowiek jest obrazem Boga również w tym niezwykłym potencjale miłości, który został w nim złożony i dzięki któremu łączy się z płcią przeciwną, zaś z tego związku powstaje nowe życie"20. Prokreacja jest zatem szczególnym przejawem owej życiodajności, będącej w człowieku wyrazem podobieństwa do Boga, jakie On sam wpisał w sens zróżnicowania płciowego mężczyzny i kobiety.

Przesłanie Księgi Rodzaju wskazuje, że Bóg oznajmił ludziom swoje pragnienie, aby świadomie i dobrowolnie współdziałali z Nim w wymiarze prokreacyjnym ${ }^{21}$. Mają być życiodajni na podobieństwo życiodajnego Boga. Dlatego człowiek, jako

\footnotetext{
13 Witczyk, „Obraz Boży”, 25-26.

14 Por. Jan Paweł II, Evangelium vitae, nr 42.

15 Jan Paweł II, Evangelium vitae, nr 43.

16 Por. Jan Paweł II, Evangelium vitae, nr 43.

17 Jan Paweł II, Evangelium vitae, nr 43.

18 Por. Franciszek, Amoris laetitia, nr 172-177.

19 Por. Kongregacja ds. Wychowania Katolickiego, Wytyczne wychowawcze, nr 22-26.

20 Chrostowski, „Ludzka cielesność”, 17.

21 Por. Katechizm Kościoła Katolickiego, nr 372.
} 
istota rozumna i wolna, może kochać oraz odpowiedzialnie kierować potencjałem wpisanym w zróżnicowanie płciowe własnego ciała. Zakłada to, że może on również odczytać sens płciowości i zgodnie z nim kształtować swoje postępowanie. A sens ten zapisany jest alfabetem zróżnicowania płciowego i manifestuje się w cielesno-psychiczno-duchowej strukturze osoby ludzkiej. Człowiek zatem, jako obraz Boży, ma być życiodajny na sposób osobowy. Należy też dodać, że wspomniana życiodajność nie wyczerpuje się jedynie w ściśle rozumianej prokreacji, ale wyraża się także poprzez ubogacający dar osoby dla osoby w miłości oblubieńczej ${ }^{22}$.

Stworzenie człowieka na obraz Boży oznacza powołanie go do istnienia z miłości i wezwanie do miłości ${ }^{23}$. Nie chodzi tu jednak o takie rozumienie miłości, które zamykałoby ją jedynie w emocjonalnym uczuciu czy nawet w intensywnym przeżyciu duchowym. Miłość w rozumieniu chrześcijańskim to postawa angażująca całą osobę. W przypadku człowieka - istoty cielesno-duchowej - oznacza to, że obok emocjonalnych i duchowych wymiarów miłości, ma ona konkretne wcielenie w słowa lub czyny, co dokonuje się właśnie dzięki ludzkiej cielesności²4. Tego uczy nas między innymi tajemnica Wcielenia Syna Bożego, który stał się człowiekiem i przyjął ciało, aby w nim i przez nie objawić najwyższą miłość i zbawić ludzkośćn ${ }^{25}$. W ten sposób w swoim człowieczeństwie objawił pełnię obrazu Bożego (por. Kol 1,15) i życiodajną moc. Myśl chrześcijańska, kontemplująca objawienie się Boga, który jest miłością $(J 4,8)$, wnosi w starotestamentowy opis stworzenia człowieka nowe treści. Bóg jest miłością i dał się poznać w trzech Osobach. A zatem Jego wewnątrztrynitarne życie wyraża się w osobowej komunii opartej na więzi miłości ${ }^{26}$. Staje się zatem jeszcze bardziej zrozumiałe, że stworzenie człowieka na obraz Boży oznacza powołanie mężczyzny i kobiety do miłości oblubieńczej oraz do dzielenia się życiem dzięki zdolności prokreacyjnej ${ }^{27}$.

W świetle powyższych stwierdzeń, wyprowadzonych z biblijnej antropologii, widzimy wyraźnie, że jakiekolwiek inne relacje intymne, wykraczające poza małżeńskie zjednoczenie mężczyzny i kobiety, burzą chciany przez Boga ład i zaciemniają w człowieku obraz Boży. W ten sposób nie tylko obrażają miłość i mądrość Stwórcy, lecz także uderzają w godność osoby ludzkiej. Objawienie Boże, ukazujące zamysł Stwórcy oraz wpisaną w naturę intymnego zbliżenia mężczyzny i kobiety celowość aktu płciowego, leży u podstaw nauki Kościoła katolickiego, „według której aktywność seksualna uzyskuje swoje prawdziwe znaczenie i godziwość moralną tylko

\footnotetext{
22 Por. Jan Paweł II, List do rodzin, nr 11.

23 Por. Jan Paweł II, Familiaris consortio, nr 11.

24 Por. Kongregacja ds. Wychowania Katolickiego, Wytyczne wychowawcze, nr 22-26.

25 Por. Chrostowski, „Ludzka cielesność”, 14-19.

26 Por. Jan Paweł II, Familiaris consortio, nr 11.

27 Por. Papieska Rada ds. Rodziny, Ludzka płciowość, nr 10.
} 
w prawowitym małżeństwie"28. Małżeństwo zaś - zgodnie z przekazem biblijnym to zawsze związek mężczyzny i kobiety.

\subsection{Jedność dwojga - od komplementarności do sakramentalnego znaku}

Mężczyzna i kobieta, stworzeni na obraz Boży, zostali uzdolnieni przez Stwórcę do zbudowania życiodajnej, międzyosobowej komunii, odzwierciedlającej wewnętrzne życie Boga ${ }^{29}$. Drugi opis stworzenia człowieka (Rdz 2,4b-25) ukazuje wspólnotową naturę osoby ludzkiej. Biblia mówi nie tylko o społecznym charakterze człowieka, ale odsłania także zasady budowania międzyludzkich więzi. Ich respektowanie pozwoli kształtować te relacje w zgodzie z mądrością i miłością Stwórcy. Ten fragment Księgi Rodzaju może także pomóc w pogłębionym spojrzeniu na problematykę homoseksualizmu.

Zapisane w pierwszej księdze Biblii słowa Pana Boga: „Nie jest dobrze, aby 'ādām był sam" (Rdz 2,18), wskazują, że samotność nie jest stanem przeznaczonym dla człowieka. Jak przypomina Papieska Komisja Biblijna, termin 'ādām w języku Biblii oznaczać może zarówno mężczyznę, jak i generalnie istotę ludzką. W cytowanym fragmencie mamy do czynienia $\mathrm{z}$ tym drugim przypadkiem, gdyż aż do wersetu 20 „narrator mówi o istocie zwanej 'ādām, abstrahując od jakiejkolwiek konotacji dotyczącej płci”30. Przywołane zdanie oznajmia zatem prawdę: nie jest dobrze, aby człowiek był sam. Ten niepożądany stan samotności oznacza w Biblii o wiele więcej aniżeli tylko przejściowe osamotnienie czy potocznie rozumiane bycie samemu. Chodzi tu o radykalna samotność, która zamyka na rozwój i nie pozwala człowiekowi realizować podobieństwa do Boga. Wynika to z dalszej części opowiadania, kiedy Stwórca prowadzi stopniowo Adama do odkrycia, kto będzie dla niego właściwa pomoca w pokonaniu owego niepożądanego stanu radykalnej samotności. Zbigniew Kiernikowski tłumaczy, że „chodzi o taką pomoc, która człowiekowi umożliwi bycie na obraz i podobieństwo Boga. Chodzi o taki «odpowiednik» [...], dzięki któremu mogłyby urzeczywistniać się podobne relacje, jakie istnieją w samym Bogu"31. W ten sposób zostanie potwierdzona także tożsamość i godność człowieka: otrzymując drugą osobę tej samej natury, ale zróżnicowaną płciowo, 'ādām został ocalony od fałszywej koncepcji bycia dla siebie i uchroniony przed ryzykiem egocentrycznego zamknięcia się w sobie ${ }^{32}$.

Interesujący jest fakt, że Bóg nie przezwycięża samotności, jakiej doświadcza 'ādām, przez stworzenie drugiego, niezróżnicowanego płciowo 'ādām. Autor natchniony wprowadza do opowiadania biblijnego zupełnie nową postać. Pozwoli to

\footnotetext{
Kongregacja Nauki Wiary, Persona humana, nr 5.

Por. Jan Paweł II, List do rodzin, nr 7.

Papieska Komisja Biblijna, Czym jest człowiek (Ps 8,5), nr 153.

Kiernikowski, Dwoje jednym ciałem, 34.

Por. Kiernikowski, Dwoje jednym ciałem, 34-35.
} 
wyartykułować kluczową prawdę o jedności natury i zarazem różnicy płciowej, które będą charakteryzowały przyszłą towarzyszkę-pomoc Adama. Narrator odwołał się tu do ciekawej i pouczającej gry słów, jaka zachodzi pomiędzy rzeczownikami 'iš (mężczyzna) i 'iššăh (kobieta). Słowa te zawierają w sobie zarówno element wspólny, jak i różnicujący, co pozwala wyrazić myśl o tym, że mężczyzna i kobieta cieszą się tą samą naturą i godnością, a jednocześnie różni ich płeć, prowadząca do wzajemnego spotkania oraz umożliwiająca intymną więź i przekazywanie życia ${ }^{33}$. Biblijne opowiadanie poucza zatem, że sam aspekt podobieństwa partnerów nie rozwiązuje problemu samotności. Dlatego biblijny 'ādām nie otrzymał od Boga drugiego identycznego płciowo 'ādām. Dopiero spotkanie w różnorodności płciowej warunkuje i umożliwia egzystencjalne wychylenie się ku drugiej osobie w taki sposób, że zaowocuje ono przekroczeniem egocentrycznych ograniczeń i stworzy podstawy dla wyjścia $z$ siebie w miłości. Ten swoisty exodus prowadzi do zjednoczenia odmiennych płciowo osób, które właśnie dzięki wspomnianemu zróżnicowaniu, są dla siebie atrakcyjne i komplementarne. Świadczy o tym reakcja Adama, który z radością wypowiada swój zachwyt na widok Ewy: „Ta dopiero jest kością z mojej kości i ciałem z mego ciała” ( $\mathrm{Rdz} 2,23)$. Słowa te podkreślają wdzięczność płynącą ze spotkania drugiej osoby, równej i zarazem różnej, która pomoże mu przezwyciężyć samotność. Użycie sformułowania „kość z moich kości, ciało z mego ciała” w logice Biblii zapowiada zawarcie przymierza pomiędzy mężczyzną a kobietą, partnerami równymi w godności, a zarazem różniącymi się od siebie ${ }^{34}$. Przymierze bowiem zawierają dwie różne strony, co aluzyjnie wyraża użycie w opisie stworzenia kobiety hebrajskiego terminu șela'. W Biblii Tysiąclecia został on przetłumaczony jako „kość”, ale najczęściej șella ' oznacza „stronę” lub „bok”. Przy pomocy tych ostatnich słów „można lepiej ukazać ideę, że mężczyzna i kobieta są jakby «bok i bok» («fianco e fianco»), podobni w swej naturze konstytutywnej; a jednocześnie są powołani, aby być «bok przy boku» («fianco a fianco»), jedno u boku drugiego, jako pomoc i sprzymierzeniec. [...] każde $\mathrm{z}$ dwojga posiada swoją specyfikę tożsamościową"35. Wspomniane wyżej przymierze stron wyraża się w pozostawieniu własnych rodziców i połączeniu się męża i żony tak ściśle, że stają się jednym ciałem (por. Rdz 2,24). Podłożem umożliwiającym tę komunię osób jest równość natury przy jednoczesnym zróżnicowaniu płciowym mężczyzny i kobiety.

Ponadczasowe przesłanie Biblii, płynące z tego fragmentu Księgi Rodzaju, jest następujące: „to nie samotności mężczyzny, ale samotności istoty ludzkiej należało zaradzić, poprzez stworzenie mężczyzny i kobiety" ${ }^{36}$. Oznacza to, że wpisana w naturę człowieka tęsknota za intymną bliskością, prowadząca do komunii osób, znajduje

\footnotetext{
33 Por. Papieska Komisja Biblijna, Czym jest człowiek (Ps 8,5), nr 155.

34 Por. Papieska Komisja Biblijna, Czym jest człowiek (Ps 8,5), nr 157.

35 Papieska Komisja Biblijna, Czym jest człowiek (Ps 8,5), nr 156.

36 Papieska Komisja Biblijna, Czym jest człowiek (Ps 8,5), nr 153.
} 
swe zaspokojenie w spotkaniu mężczyzny z kobietą, a kobiety z mężczyzną. Zróżnicowanie płciowe ukierunkowuje na to spotkanie, a komplementarność płci umożliwia ścisłe zespolenie męża i żony tak, że stają się jednym ciałem. Wszelkie inne próby zaspokojenia tej intymnej tęsknoty, wychodzące poza relację heteroseksualną, stoją w sprzeczności z Bożym zamysłem i łamią naturalną celowość wpisaną w logos zróżnicowania płciowego, co człowiek może rozeznać światłem naturalnego rozumu.

Kongregacja Nauki Wiary zauważa, że „zawarta w Księdze Rodzaju teologia stworzenia stanowi podstawowy punkt wyjścia do adekwatnego zrozumienia problemów związanych z homoseksualizmem" ${ }^{37}$. Przypomina także dalsze wydarzenia zapisane na kartach tej księgi, które wyjaśniają, w jaki sposób prawda o obrazie Bożym w człowieku została przyćmiona przez odwrócenie się pierwszych ludzi od Boga (por. Rdz 3). Moralne zepsucie zamanifestowało się m.in. w przemocy Kaina wobec Abla oraz w wykroczeniach mieszkańców Sodomy (por. Rdz 19,1-11). Grzech pierworodny sprawił osłabienie świadomości małżeńskiego znaczenia ludzkiego ciała, a będąca jego skutkiem pożądliwość, kieruje ludzi do zaspokajania swoich pragnień niezgodnie z Bożą mądrością i miłością. Zwraca na ten fakt uwagę św. Paweł, kiedy w Liście do Rzymian pochyla się nad problemem wykroczeń moralnych będących skutkiem odwrócenia się od Boga (por. Rz 1,18-32). Odrzucenie Bożego zamysłu skutkuje - zdaniem Apostoła Narodów - popadnięciem w niewolę namiętności, prowadzących między innymi do stosunków homoseksualnych wśród mężczyzn i kobiet. Surowa ocena tych czynów powróci w innych tekstach nowotestamentowych, traktujących praktyki homoseksualne jako ciężkie wykroczenie moralne, wykluczające z Królestwa Bożego (por. 1 Kor 6,9).

Opis grzesznej kondycji człowieka niezdolnego do podjęcia swego pierwotnego powołania nie jest jednak ostatnim słowem antropologii teologicznej. Uwikłany w swe słabości i rozdarty wewnętrznie człowiek (por. Rz 7, 14-25) nie został opuszczony przez Pana Boga. W dziejach ludzkości Bóg cały czas wychodzi do człowieka i proponuje mu wciąż na nowo swoją zbawczą bliskość. Szczytem tej bliskości stało się Wcielenie Syna Bożego i podjęte przez Niego dzieło Odkupienia. W Misterium Paschalnym Bóg ostatecznie przezwycięża grzech i przywraca człowiekowi utraconą godność dziecka Bożego. W ten sposób ponownie staje się możliwe coraz pełniejsze odzwierciedlanie obrazu Boga w człowieku. W odniesieniu do związku mężczyzny i kobiety Chrystus przywraca pierwotną prawdę o małżeństwie jako trwałej wspólnocie osób (por. Mt 19,6), biorącej początek z tajemnicy trynitarnego „My”38. Krucha i nietrwała ludzka miłość, włączona dzięki sakramentowi chrztu i małżeństwa w miłość Bożą ${ }^{39}$, nabiera nowej mocy i wymiaru świadectwa. Dzięki temu relacja dwojga może stać się komunią osób na wzór Trójcy Świętej i znakiem miłości Boga

\footnotetext{
37 Kongregacja Nauki Wiary, Homosexualitas problema, $\mathrm{nr} 6$.

38 Por. Jan Paweł II, List do rodzin, nr 8.

39 Por. Jan Paweł II, Familiaris consortio, nr 13.
} 
do ludzi. W przymierzu oblubieńczym mężczyzna i kobieta ukazują miłość Chry-

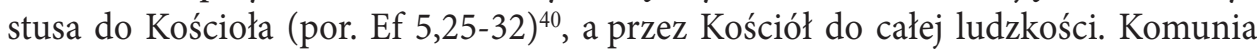
małżeńska stanowi punkt wyjścia dla kształtowania szerszej komunii rodzinnej, budowanej na więzach naturalnych oraz na nadprzyrodzonej relacji do Chrystusa, od którego wszyscy członkowie rodziny mogą uczyć się prawdziwego braterstwa ${ }^{41}$.

Wymiar oblubieńczy ukazany w paralelnej relacji Chrystus/mąż - Kościół/żona stanowi nowotestamentową rekapitulację fundamentalnych tez antropologii biblijnej w zakresie ludzkiej płciowości. Pierwotny zamysł Boży został potwierdzony i odnowiony przez dzieło Odkupienia. Boża miłość uobecnia się w świecie za pośrednictwem osobowej komunii mężczyzny i kobiety, których zróżnicowanie płciowe umożliwia intymną bliskość, wzajemne oddanie się sobie oraz promieniowanie życiodajnością. Droga ta oznacza także pojawienie się wymagających wyzwań wpisanych w spotkanie osób zróżnicowanych płciowo. Podejmowanie tych wyzwań jest konieczne dla osiągania dojrzałości osobowej każdego z małżonków, którzy ubogacają się wzajemnie przez otwieranie się na różnicę uwarunkowaną płciowo: na to, kim jest druga strona w swej odmienności (fizycznej, psychicznej i duchowej) i co wnosi ona do związku. Tego aspektu nie odnajdziemy w relacji homoseksualnej. Wzajemne obdarowanie związane z różnicą płciową, niosąc ze sobą zadanie dialogu w różnorodności, odsłania jeszcze inny wymiar życia osobowego, a mianowicie zdolność do przekraczania siebie, integrowania różnicy. Krótko mówiąc: wspomniane wzajemne obdarowanie jest przestrzenią ujawniania się osobowej transcendencji - w czym dostrzec możemy realizację ewangelicznego wezwania do chrześcijańskiej doskonałości (por. Mt 5,48) i sposób pielęgnowania w człowieku obrazu Bożego.

\section{Moralna ocena homoseksualizmu oraz jej eklezjalne i społeczne konsekwencje}

Odnowione spojrzenie na moralność chrześcijańską, jakie wypracował Sobór Watykański II, wiązało się z odejściem od legalizmu i minimalizmu przedsoborowej teologii moralnej i zwróceniem się do biblijnej prawdy o powszechnym powołaniu do świętości. Oznaczało to postulat pozytywnego wykładu treści moralnych wpisanych w Ewangelię, gdyż jest ona przecież dobrą nowina dla człowieka, który jako osoba „nie może się w pełni odnaleźć inaczej, jak tylko przez szczery dar z siebie samego"42. Człowiek został stworzony przez Boga z miłości i powołany do miłości. W ten sposób sobór wytyczył biblijno-personalistyczną perspektywę rozstrzygania dylematów

\footnotetext{
40 Por. Kongregacja Nauki Wiary, Persona humana, nr 7.

41 Por. Kongregacja Nauki Wiary, Persona humana, nr 21.

42 Por. Sobór Watykański II, Gaudium et spes, nr 24.
} 
moralnych pojawiających się w czasach naznaczonych szybkim postępem cywilizacyjnym i pokusą podważania dotychczasowych pewników.

Katolicka etyka seksualna, formułując ocenę moralną homoseksualizmu, będzie zatem uwzględniać przesłanki normatywne, wypływające zarówno z Bożego Objawienia, jak i z natury osoby ludzkiej ${ }^{43}$. Oznacza to gotowość do interdyscyplinarnego dialogu i otwartość na wkład różnych nauk o człowieku, w których porusza się zagadnienia seksualności i płciowości.

\subsection{Znaczenie dystynkcji skłonność - czyny w ocenie moralnej}

Przedstawione w pierwszej części artykułu główne tezy antropologii biblijnej ukazały małżeństwo mężczyzny i kobiety jako zasadniczą i ewidentną normę moralną w odniesieniu do ludzkiej płciowości. Norma ta, jak zauważa Papieska Komisja Biblijna, jest obecna bez wyjątków w całej tradycji biblijnej, w której nie znajdziemy „przykładów prawnie uznanego «związku» między osobami tej samej płci" ${ }^{4}$. Co więcej, zarówno Stary, jak i Nowy Testament dostarczają nam czytelnych dowodów dezaprobaty czy wręcz potępienia dla praktyk homoseksualnych (por. Kpł 18,22; Rz 1, 26-27; 1 Kor 6,9; 1 Tm 1,10).

Kościół katolicki, wierny temu przesłaniu, wyjaśnia współczesnemu światu antropologiczne i teologiczne racje przemawiające za takim stanowiskiem. Podstawą dla moralnej oceny homoseksualizmu jest zawarta w Piśmie Świętym teologia stworzenia $^{45}$. W świetle antropologii biblijnej widzimy, że relacjom homoseksualnym brak wymiaru jednoczącego, opartego na komplementarności płci, oraz wymiaru prokreacyjnego, związanego ze zróżnicowaniem płciowym mężczyzny i kobiety ${ }^{46}$. Magisterium postuluje jednak, aby odczytaną z Objawienia normę obiektywną - jak to zresztą bywa w każdej ocenie moralnej ludzkiego czynu - stosować roztropnie, z uwzględnieniem uwarunkowań osobowościowych oraz zewnętrznych okoliczności, mających wpływ na ostateczny osąd moralny. Deklaracja Persona humana wyraża ten postulat w następujący sposób: „Według obiektywnego porządku moralnego stosunki homoseksualne są pozbawione niezbędnego i istotnego uporządkowania. W Piśmie Świętym są one potępione jako poważna deprawacja [...]"47. Jednakże zaraz dodaje się istotne dopowiedzenie: „Sąd ten nie uprawnia do stwierdzenia, że wszyscy dotknięci tą nieprawidłowością mają tym samym winę osobistą" ${ }^{38}$. Sugeruje to potrzebę bardziej pogłębionej refleksji nad samym fenomenem homoseksualizmu,

\footnotetext{
43 Por. Kongregacja Nauki Wiary, Persona humana, nr 5.

44 Papieska Komisja Biblijna, Czym jest człowiek (Ps 8,5), nr 185.

45 Por. Kongregacja Nauki Wiary, Homosexualitas problema, nr 5-6.

46 Por. Melina, „Criteri morali”, 105-106.

47 Kongregacja Nauki Wiary, Persona humana, nr 8.

48 Kongregacja Nauki Wiary, Persona humana, nr 8.
} 
a przy formułowaniu oceny moralnej - uwzględnienie ważnego rozróżnienia pomiędzy skłonnością homoseksualną a praktykowaniem aktów homoseksualnych.

Na samym początku należy przypomnieć, że wrażliwość na powyższe rozróżnienie kształtowała się w posoborowym magisterium nie bez pewnych trudności. Nauczanie zawarte w deklaracji Persona humana wychodzi od przytoczenia poglądu inspirowanego racjami psychologicznymi, mówiącego o istnieniu dwóch kategorii osób homoseksualnych. Pierwszą z nich stanowią osoby, których „skłonność wynika z błędnego wychowania lub z braku dojrzałości seksualnej, bądź z przyzwyczajenia lub złego przykładu, czy z innych podobnych przyczyn, występuje tylko okresowo lub przynajmniej nie jest nieuleczalna"49. Chodziłoby zatem o przejawy nabyte, utrwalone pod wpływem zewnętrznych czynników, w przeciwieństwie do przejawów charakteryzujących drugą kategorię osób homoseksualnych, doświadczających skłonności utożsamianych z pewnego rodzaju wewnętrznym popędem lub patologiczną konstytucją, traktowaną jako nieuleczalną ${ }^{50}$. Dopuszczając możliwość takiego rozróżnienia, autorzy deklaracji zwrócili jednak uwagę na niepokojące próby usprawiedliwiania homoseksualizmu na podstawie wspomnianej wewnętrznej tendencji, która przez niektórych psychologów, czy nawet teologów, uznawana jest za „naturalną”, co miałoby uzasadniać moralną godziwość stosunków homoseksualnych ${ }^{51}$. W odpowiedzi na tego rodzaju próby Magisterium przywołało negatywną ocenę praktyk homoseksualnych zawartą w Piśmie Świętym. Przypominając o konieczności duszpasterskiej łagodności w stosunku do osób homoseksualnych i uwrażliwiając na roztropne orzekanie o winie subiektywnej, stwierdziło jednak ze stanowczością, że „akty homoseksualizmu są wewnętrznie nieuporządkowane i w żadnym wypadku nie mogą zostać zaaprobowane" ${ }^{\prime \prime 2}$.

Opublikowana na początku 1976 r. deklaracja wzbudziła żywą dyskusję zarówno w Kościele katolickim, jak i poza nim. Niektóre środowiska spodziewały się być może innych rozstrzygnięć, aniżeli te zawarte w watykańskim dokumencie. Nadzieje rozbudzała m.in. publikacja amerykańskiego jezuity Johna McNeilla The Church and the Homosexual. Książka ta pojawiła się na rynku amerykańskim w 1976 r. (we Włoszech w 1979 r.), a zatem niemalże równolegle z deklaracją Kongregacji Nauki

\footnotetext{
49 Kongregacja Nauki Wiary, Persona humana, nr 8.

50 Por. Kongregacja Nauki Wiary, Persona humana, nr 8.

51 Z tym zagadnieniem łączy się problematyka przyczyn wywołujących skłonność i czyny homoseksualne. Ze względu na obszerność tego zagadnienia oraz opracowanie go w licznych publikacjach, w tym miejscu zostaje ono tylko zasygnalizowane. Przyczynami homoseksualizmu mogą być: niewłaściwe relacje rodzic dziecko, zakłócona relacja z rodzeństwem, brak akceptacji płci dziecka ze strony rodziców, nieakceptacja własnej płci, liberalizm wychowawczy, narcyzm lub kompleks niższości, seksualne doświadczenia w dzieciństwie, promieniowanie subkultury homoseksualnej. Niektórzy upatrują przyczyny homoseksualizmu w czynnikach biologicznych, takich jak struktura genetyczna czy mechanizmy epigenezy. Por. Kieniewicz, „Homoseksualizm”, 203-217; Orzeszyna, „Skłonności homoseksualne”, 133-152; Paszewski, „Przyczyny orientacji", 31-43.

52 Kongregacja Nauki Wiary, Persona humana, nr 8.
} 
Wiary. Amerykański jezuita przekonywał o możliwości istnienia godziwych moralnie relacji homoseksualnych w przypadku, gdyby te opierały się na konstruktywnym altruizmie, a nie na destruktywnym egoizmie ${ }^{53}$. Inni komentatorzy deklaracji wnioskowali, że skoro dokument mówi wprost o niegodziwości samych aktów homoseksualnych, a nie precyzuje dokładniej kwalifikacji moralnej predyspozycji do takiego działania, można by uznać tę skłonność za dobrą. W konsekwencji - według tych poglądów - czyny wynikające z dobrej dyspozycji nie muszą być zawsze złe moralnie. Rozumowanie tego typu dało w Kościele katolickim początek nurtowi aprobującemu praktyki homoseksualne podejmowane w klimacie wiernej miłości czy wspomnianego wcześniej konstruktywnego altruizmu ${ }^{54}$. Interpretacje tego typu odbiegały jednak w swej treści od moralnego przesłania deklaracji Persona humana, co wyraźnie podkreśliła Kongregacja Nauki Wiary w Liście do biskupów Kościoła katolickiego poświęconym duszpasterstwu osób homoseksualnych ${ }^{55}$.

List Homosexualitas problema został opublikowany przeszło dekadę po deklaracji Persona humana. Zbierał zatem doświadczenia minionego dziesięciolecia w zakresie recepcji doktryny Kościoła, jak i rozwijającej się praktyki pastoralnej. Zachęcając do uważnego studium i teologicznie wyważonej refleksji nad zjawiskiem homoseksualizmu, Kongregacja Nauki Wiary wyraziła ubolewanie z powodu pojawienia się interpretacji nadmiernie przychylnych predyspozycji homoseksualnej. Niektórzy komentatorzy uznali ją za moralnie obojętną czy nawet dobrą. Nie jest to jednak zgodne z wykładnią Magisterium Kościoła. Stąd też list do biskupów wprowadza pewne istotne uściślenie, precyzujące stanowisko wyrażone w deklaracji z 1975 r. Kongregacja wyjaśnia, że błędnie interpretowana predyspozycja homoseksualna, „choć sama w sobie nie jest grzechem, to jednak stwarza mniej lub bardziej silną skłonność do postępowania, które z punktu widzenia moralnego jest złe. Z tego powodu sama skłonność musi być uważana za obiektywnie nieuporządkowaną"56. To bardzo istotne dopowiedzenie, rozwiewające wątpliwości, które pojawiły się po opublikowaniu deklaracji Persona humana.

Aby zrozumieć lepiej wagę tego dopowiedzenia i jego znaczenie dla formułowania ocen moralnych, należy przyjrzeć się bliżej, co znaczy, że skłonność homoseksualna jest „obiektywnie nieuporządkowana”. Jak zauważa Livio Melina, wyrażenie to najpierw odsyła nas do obiektywnego porządku rzeczywistości, który w katolickiej

53 Por. Augustyn, „Zjawisko homoseksualizmu”, 138.

54 Współcześnie reprezentantami tego poglądu są przykładowo dwaj teologowie amerykańscy Todd A. Salzman i Michael G. Lawler. Powołując się na słowa „Jeżeli miłujemy się wzajemnie, Bóg twa w nas i miłość ku Niemu jest w nas doskonała” (1 J 4,12), uzasadniają, że nie może być różnicy pomiędzy miłością małżeńską a miłością osób tej samej płci, gdyż w jednej i drugiej relacji mieszka Bóg. Por. Kupczak, Amoris laetitia, 250-251. 
tradycji moralnej jest podstawą umożliwiającą jakąkolwiek ocenę czy sąd ${ }^{57}$. W praktyce oznacza to opowiedzenie się za realizmem otaczającego nas świata oraz możliwością jego poznawania i docierania do prawdy, w tym prawdy moralnej. Świat ten daje się poznać jako uporządkowany, racjonalny i odbijający w sobie mądrość boskiego Stwórcy. Porządek w świecie wiąże się z powszechną właściwością istniejących w nim bytów, które realizują swoją własną celowość. W ten sposób dążą do zrealizowania swojej natury, czyli istnieja i staja się zgodnie z tym, co stanowi ich istotę. W tym wyraża się logos porządku, a sam porządek jest wyrazem mądrości. Rozum ludzki jest w stanie te procesy oraz cele poznawać i systematyzować w postaci wiedzy. „To właśnie poprzez wyznaczanie celów opatrznościowa mądrość Boga porządkuje świat. A poprzez rozpoznawanie celów uprzednio ustanowionych w planie Boga, człowiek mądry może porządkować swoje działania i dyspozycje"58. Dodać tu jednak należy, że wskutek grzechu pierworodnego człowiek nie zawsze z łatwością rozpoznaje wpisany w naturę bytów porządek stwórczy, co więcej, skutki pierwszego grzechu rozlały się także na całe stworzenie, powodując $w$ nim zachwianie pierwotnego ładu ${ }^{59}$. „Stworzenie zostało poddane marności” (Rz 8,20) - pisał św. Paweł. Przejawem tego stanu w człowieku jest łatwość, z jaką zmysłowość wymyka się spod kontroli rozumu i prowadzi do wyborów sprzecznych z porządkiem moralnym. Jakkolwiek podłożem etycznie złych wyborów mogą być skłonności upadłej natury, to człowiek nie jest skazany na ich dominację i stan rozdarcia, lecz może odnaleźć moc do ich przezwyciężenia dzięki wierze w Chrystusa Jezusa (por. Rz 7,14-24). W tym pozytywnym kluczu należy interpretować każde nieuporządkowanie moralne wynikające ze skutków grzechu pierworodnego. Wiara w Chrystusa pozwala z optymizmem spoglądać także na upadki, jakich człowiek doświadcza w sferze seksualnej. Żadne uwarunkowanie somatyczne czy środowiskowe nie jest silniejsze od wolności osoby odkupionej w Chrystusie ${ }^{60}$.

Sformułowanie „obiektywnie nieuporządkowana skłonność”, odniesione do homoseksualizmu, oznacza charakterystykę tendencji, w których „elementy osobowości są tak dysponowane, że nie ukierunkowują one podmiotu na osiągnięcie celu, jaki plan Boży przypisuje seksualności”61. W efekcie człowiek nie postępuje zgodnie z celowością wpisaną w cielesny wymiar własnej osoby. Obiektywnie nieuporządkowana skłonność homoseksualna stanowi poważną przeszkodę w realizacji Bożego zamysłu dotyczącego przeżywania ludzkiej płciowości. Jeśli nie jest ona rezultatem osobistego wyboru, nie może obciążać odpowiedzialnością. Jednakże jako czynnik ułatwiający złe wybory moralne, nie jest zupełnie obojętna i powinna zostać otoczona szczegól-

\footnotetext{
57 Por. Melina, „Skłonność homoseksualna”, 155-156.

58 Melina, „Skłonność homoseksualna”, 156.

59 Por. Katechizm Kościoła Katolickiego, nr 400.

60 Por. Jan Paweł II, Veritatis splendor, nr 103.

61 Melina, „Skłonność homoseksualna”, 156.
} 
ną troską duszpasterską ${ }^{62}$. Pogłębiająca się skłonność może z czasem coraz bardziej osłabiać wrażliwość moralną i prowadzić do tego, że człowiek, w poczuciu egocentrycznej mocy, zaczyna traktować siebie jak tworzywo we własnych rękach, zaprzeczając swojej osobowej naturze ${ }^{63}$. Zapomina, że ,jest dla siebie samego darem otrzymanym od Boga i dlatego musi respektować naturalną i moralną strukturę, w jaką został wyposażony" ${ }^{64}$. Dostrzeżenie związku przyczynowego pomiędzy skłonnością a konkretnymi czynami postuluje włączenie nieuporządkowanej predyspozycji w program pracy wewnętrznej, podobnie jak w sytuacji innych moralnych niedomagań, które powiązane są z uwarunkowaniami osobowościowymi (np. ze skłonnością do agresji czy nadpobudliwością seksualną).

W takim kierunku orientuje refleksję na temat homoseksualizmu nauczanie zawarte w Katechizmie Kościoła Katolickiego. Magisterium pochyla się z troską nad osobami, które same nie dokonały wyboru swojej kondycji homoseksualnej, ale odkryły ją w sobie jako „głęboko osadzoną skłonność"65. Dla wielu z tych osób jest ona trudnym doświadczeniem. Wrażliwość chrześcijańska nakazuje takie osoby otoczyć szacunkiem i zaprasza je na drogę wypełniania woli Bożej. Jeżeli wyznają wiarę w Chrystusa, są powołane do włączania swych trudności w Jego zbawczą ofiarę. Jest dla nich miejsce w Kościele, który dysponuje środkami duchowego wsparcia, aby dopomóc im w realizacji chrześcijańskiego powołania. Jak wszyscy chrześcijanie, osoby homoseksualne są wezwane do czystości. W ich sytuacji oznacza to unikanie okazji do grzechu i wezwanie do abstynencji w dziedzinie współżycia płciowego. Z pewnością nie jest to łatwe zadanie, ale z Bożą pomocą zawsze możliwe, gdyż „Bóg z tymi, którzy Go miłują, współdziała we wszystkim dla ich dobra” (Rz 8,28). Osoby homoseksualne są zaproszone do tego, aby rozwijać cnotę panowania nad sobą, a w grupie bezinteresownych przyjaciół znajdować ludzkie wsparcie. Nie powinny zapominać także o regularnej modlitwie i życiu sakramentalnym, będącymi źródłem Bożej łaski. Wzmacnia ona siły do pracy wewnętrznej i sprawność panowania nad pragnieniami. Wszystkie te środki stanowią niezawodną pomoc na drodze stopniowego wzrostu w doskonałości chrześcijańskiej ${ }^{66}$.

\subsection{Implikacje w życiu Kościoła i społeczeństwa}

Zaprezentowana powyżej moralna ocena zjawiska homoseksualizmu niesie ze sobą pewne wyzwania pastoralne. Dotyczą one zarówno szeroko rozumianej troski o głoszenie chrześcijańskiej antropologii i personalistycznej etyki seksualnej, jak również rozwoju duszpasterstwa specjalistycznego dedykowanego wprost osobom o skłon-

\footnotetext{
62 Por. Kongregacja Nauki Wiary, Homosexualitas problema, nr 3; Melina, „Skłonność homoseksualna”, 154.

63 Por. Franciszek, Laudato si, nr 115.

64 Franciszek, Laudato si, nr 115.

65 Por. Katechizm Kościoła Katolickiego, nr 2358.

66 Por. Katechizm Kościoła Katolickiego, nr 1359.
} 
nościach homoseksualnych. Stanowisko Kościoła znajduje także swój rezonans w społeczności świeckiej. Ta ostatnia bowiem, choć sama w sobie może być religijnie i kulturowo zróżnicowana, to jednak na mocy faktu, że stanowi wspólnotę osób, jest zobowiązana do respektowania zasad prawa naturalnego. Prawo to, jako fundamentalny zmysł moralny wspólny wszystkim ludziom, „wyraża i wskazuje cele, uprawnienia i obowiązki, których podstawą jest cielesna i duchowa natura osoby ludzkiej”' ${ }^{67}$. Zasady tego prawa są możliwe do poznania światłem rozumu, a Objawienie chrześcijańskie potwierdza je jako wyraz Bożej mądrości i miłości.

\section{a) Wrażliwość pastoralna i duszpasterstwo osób homoseksualnych}

Posoborowe dokumenty Kościoła poświęcone ludzkiej płciowości zachęcają, aby w działaniach duszpasterskich przybliżać wiernym chrześcijańską antropologię i wynikającą z niej personalistyczną etykę seksualną. Szczególnie ważnym okresem kształtowania się właściwego podejścia człowieka do własnej płciowości jest czas dojrzewania. Stąd troska duszpasterska powinna objąć w wyjątkowy sposób dzieci i młodzież. W ramach szeroko rozumianej posługi duszpasterskiej, w katechezie, przepowiadaniu oraz podczas innych spotkań z młodymi, należy pomagać im w odkrywaniu sensu płciowości, jaki Pan Bóg wpisał w tożsamość mężczyzny i kobiety ${ }^{68}$. Jest to szczególnie ważne w kontekście silnej i nachalnej ofensywy ze strony środowisk promujących nowe sposoby interpretacji ludzkiej płciowości, które kwestionują binarność płci, deprecjonują rolę macierzyństwa i ojcostwa, relatywizują misję małżeństwa i rodziny ${ }^{69}$.

Poważnym problemem jest także rozeznanie zdatności do sakramentu święceń osób wykazujących skłonności homoseksualne lub praktykujących homoseksualizm $^{70}$. W specjalnej instrukcji na temat rozeznawania powołania w stosunku do takich osób Stolica Apostolska podkreśla znaczenie dojrzałości uczuciowej i zdolności kandydatów do duchowego ojcostwa. Mając na uwadze całość nauczania Kościoła katolickiego na temat homoseksualizmu, a jednocześnie szanując osoby, których ten problem dotyczy, Kościół „nie może dopuszczać do seminarium ani do święceń osób, które praktykują homoseksualizm, wykazują głęboko zakorzenione tendencje homoseksualne lub wspierają tak zwaną "kulturę gejowską»" "11. Powodem takiej decyzji jest przekonanie o moralnej kondycji wyżej wymienionych osób, która utrudnia czy wręcz uniemożliwia właściwe relacje z mężczyznami i kobietami. W tym samym dokumencie stwierdza się, że inaczej można by potraktować tendencje homoseksualne, będące przejawem przejściowego problemu (związanego np. z procesem dorastania).

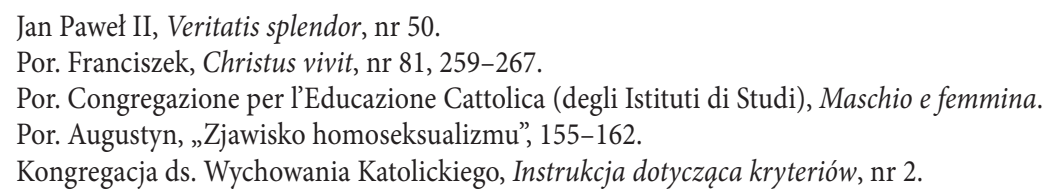

Jan Paweł II, Veritatis splendor, nr 50.

Por. Franciszek, Christus vivit, nr 81, 259-267.

Por. Congregazione per l'Educazione Cattolica (degli Istituti di Studi), Maschio e femmina.

Por. Augustyn, „Zjawisko homoseksualizmu”, 155-162.

Kongregacja ds. Wychowania Katolickiego, Instrukcja dotycząca kryteriów, nr 2. 
W takim przypadku wspomniane tendencje musiałyby jednak zostać zdecydowanie przezwyciężone przynajmniej trzy lata przed przyjęciem święceń diakonatu ${ }^{72}$.

W obliczu silnych trendów lansujących homoseksualizm jako jeden $\mathrm{z}$ alternatywnych sposobów przeżywania ludzkiej płciowości, Kościół katolicki jest wezwany do podjęcia wielowymiarowych wysiłków duszpasterskich, poprzez które będzie mógł przyjść z konkretną pomocą osobom o skłonnościach homoseksualnych, a jednocześnie uchronić Boży zamysł względem mężczyzny i kobiety od błędnych interpretacji. Zagadnienia te były poruszane w posoborowych wypowiedziach Magisterium Kościoła, wzywających biskupów, kapłanów i wiernych świeckich do czujności, aby nie mylić świadectwa miłości względem osób homoseksualnych z aprobatą dla ich homoseksualnej aktywności.

Z powyższej motywacji wynika sformułowana przez Kongregację Nauki Wiary zachęta do rozwijania duszpasterstwa osób o skłonnościach homoseksualnych. W liście Homosexualitas problema czytamy, że wymagana od wszystkich postawa szacunku i niedyskryminacji wobec osób homoseksualnych nie jest równoznaczna $\mathrm{z}$ twierdzeniem, że „predyspozycje homoseksualne nie są moralnie nieuporządkowane"73. Przyjęcie takiego założenia prowadziłoby z konieczności do uznania samej aktywności homoseksualnej za dobrą, co stoi w wyraźnej sprzeczności z wolą Bożą i naturą osoby ludzkiej. Zgoda na taki kierunek rozbudza w konsekwencji nieuzasadnione żądania uznania związków tej samej płci przez ustawodawstwo państwowe. Nierzadko postuluje się, aby podobne rozwiązania zostały przyjęte we wspólnotach wyznaniowych ${ }^{74}$.

Niebezpieczeństwo tego typu błędów może być zażegnane tylko wtedy, gdy Kościół podejmie konkretne działania formacyjne, pozwalające z jednej strony nieść pomoc tym, którzy jej szukają we wspólnocie wiary, a z drugiej głosić pełną prawdę na temat homoseksualizmu. „Tylko to, co prawdziwe, może być w ostatecznym rozrachunku także pastoralne"75 - przypomina Kongregacja Nauki Wiary, która zgodnie z tą zasadą - w dokumencie Responsum ad dubium z roku 2021 definitywnie wykluczyła możliwość udzielania błogosławieństwa związkom osób tej samej płci, gdyż nie są one ukierunkowane zgodnie z zamysłem Stwórcy.

Co zatem konkretnie powinno zostać uwzględnione w programie duszpasterskim skierowanym do osób o skłonnościach homoseksualnych? Posłudze pastoralnej winien zawsze przyświecać postulat otwartości i prymat logiki przyjęcia nad pokusą odrzucenia. O postawie tej przypomina papież Franciszek, którego wypowiedzi $\mathrm{w}$ tym względzie bywają niekiedy interpretowane jako oznaki zmian doktrynalnych

\footnotetext{
72 Por. Kongregacja ds. Wychowania Katolickiego, Instrukcja dotycząca kryteriów, nr 2.

73 Kongregacja Nauki Wiary, Homosexualitas problema, nr 10.

74 Por. Kongregacja Nauki Wiary, Homosexualitas problema, nr 9-10; Kongregacja Nauki Wiary, Responsum ad dubium.

75 Kongregacja Nauki Wiary, Homosexualitas problema, nr 15.
} 
w spojrzeniu na homoseksualizm ${ }^{76}$. Analiza nauczania Kościoła z okresu aktualnego pontyfikatu nie potwierdza jednak tych sugestii ${ }^{77}$. W swoich wypowiedziach papież nie zmienia moralnej oceny praktyk homoseksualnych, ale uwzględniając motywy duszpasterskie, ostrzega przed pochopnym osądzaniem osób ze skłonnościami homoseksualnymi i widzi dla nich miejsce we wspólnocie wiary.

Osoby odkrywające w sobie skłonność homoseksualną nie są wykluczone ipso facto ze wspólnoty Kościoła. Jest wręcz odwrotnie. Ich osobista sytuacja jest powodem, dla którego powinny się w tej wspólnocie znaleźć. W Kościele bowiem mogą otrzymać ludzkie i nadprzyrodzone wsparcie, którego poszukują być może w niewłaściwych miejscach i relacjach. Miłość Boga jest najpotężniejszym sprzymierzeńcem w ich trudnej sytuacji. I to właśnie ta miłość nie pozwala interpretować homoseksualnej skłonności jako bezwzględnej determinanty zmuszającej do zachowań homoseksualnych. Podczas gdy niektórzy w tym właśnie czynniku zdeterminowania upatrują okoliczność zwalniającą od moralnej odpowiedzialności za podejmowane działanie, to stanowisko Kościoła przestrzega tu przed zbyt pochopnym pozbawianiem konkretnego człowieka jego najbardziej podstawowych władz i funkcji osobowych. Tłumaczenie postępowania silną determinacją płynącą ze skłonności homoseksualnej jest jednoznaczne z odmówieniem człowiekowi możliwości decydowania o sobie i wpływu na własne wybory. Tymczasem Kościół uczy, że traktując osobę z miłością, „trzeba wystrzegać się bezpodstawnego i upokarzającego domniemania, że zachowanie homoseksualne osób homoseksualnych zawsze i całkowicie podlega przymusowi i dlatego nie stanowi winy"78.

Analizując tę sytuację w perspektywie chrześcijańskiego personalizmu, dostrzegamy w każdym człowieku (także w tym ze skłonnością homoseksualną) najpierw osobę - istotę rozumną i wolną - co przypomina o jego szczególnej godności. To właśnie osobowe władze, świadomość i wolność, są szansą, że „ludzki wysiłek oświecony i wsparty łaską Bożą może powstrzymać te osoby od homoseksualnej aktywności" ${ }^{\prime \prime 9}$. Można by zaryzykować stwierdzenie, że ocena możliwości moralnych osoby homoseksualnej zależy od tego, czy widzimy w niej (i ona sama widzi w sobie) przede wszystkim osobę z jej potencjalnością przekraczania siebie i swoich ograniczeń moralnych (transcendencja), czy raczej koncentrujemy się na homoseksualnej predyspozycji, traktując ją jako czynnik wyłączający sprawność wolnej woli, co ostatecznie byłoby brutalną depersonalizacją człowieka ${ }^{80}$.

\footnotetext{
76 Na temat publicystycznych nadinterpretacji wypowiedzi papieża Franciszka zob. Przeciszewski, „Papież Franciszek”.

77 Por. Franciszek, Amoris laetitia, nr 250-251.

78 Kongregacja Nauki Wiary, Homosexualitas problema, nr 11.

79 Kongregacja Nauki Wiary, Homosexualitas problema, nr 11.

80 Por. Kongregacja Nauki Wiary, Homosexualitas problema, nr 16. Szerszy kontekst duchowy i moralny tego problemu porusza Jan Paweł II w Veritatis splendor nr 103.
} 
Utrwalanie świadomości, że osoba jest zniewolona swoją skłonnością i nie może nic innego zrobić, jak tylko poddać się tej predyspozycji, jest z punktu widzenia antropologii chrześcijańskiej upokarzające i niedopuszczalne. Kościół katolicki nie zgadza się z taką optyką i dlatego proponuje osobom o skłonnościach homoseksualnych podjęcie duchowej formacji, zakładającej wejście na drogę pełnienia woli Bożej. Oznacza to m.in. otwieranie się na dary Ducha Świętego i przynoszenie Jego owoców, które pozwalają „ukrzyżować ciało z jego namiętnościami” (por. Ga 5,22-24). Jak każdy inny chrześcijanin zmagający się w własnymi słabościami, osoba homoseksualna otrzymuje w Kościele możliwość osobistego przejścia z Chrystusem przez Misterium Paschalne, aby obumrzeć grzechowi i powstać do nowego życia, pielęgnując czystość myśli, pragnień, spojrzeń i czynów. Pomagać mu w tym będzie modlitwa, rozważanie Bożego słowa, sakramenty święte, zwłaszcza sakrament pokuty i pojednania. Możliwe jest także skorzystanie z profesjonalnej opieki specjalistycznej z zakresu psychologii lub innych dziedzin ${ }^{81}$.

Propozycja katolicka, odwołując się do osobowej godności człowieka, szanuje jego wolę i proponuje mu drogę najbardziej odpowiadającą ludzkim aspiracjom: dążenia do prawdy i do wolności, a ostatecznie do miłości, której człowiek pragnie, szukając jej nie zawsze we właściwych miejscach i relacjach. Kościół wskazuje mu zatem źródło tej miłości. Jest nim Bóg przywracający każdemu człowiekowi pełnię osobowej tożsamości w Chrystusie. Na drodze wiary możliwe jest uzdrowienie, które nie zawsze musi oznaczać zmianę predyspozycji homoseksualnej ${ }^{82}$, lecz jest szansą na odzyskanie „pełni zdrowia w Chrystusie” ${ }^{\text {" }}$.

\section{b) Postawa wobec prawnej legalizacji związków osób tej samej płci}

Postępująca w szybkim tempie akceptacja społeczna dla homoseksualnego stylu życia spowodowała, że w wielu krajach ustawodawstwo państwowe zaakceptowało najpierw związki partnerskie osób tej samej płci, a następnie również tzw. małżeństwa homoseksualne. Przychylność wobec tego typu rozwiązań wyrażał (i wciąż wyraża) także Parlament Europejski. Wobec takiej postawy unijnych urzędników w 1994 r. stanowczo zaprotestował papież Jan Paweł II. Jego zdaniem „Parlament w sposób nieuprawniony nadał walor prawny zachowaniom dewiacyjnym, niezgod-

81 Por. Kongregacja Nauki Wiary, Homosexualitas problema, nr 12-15.

82 Dla osób chętnych nie jest wykluczone podjęcie terapii prowadzącej do uzdrowienia różnego rodzaju zranień osobowościowych, co może spowodować zmianę w postrzeganiu i przeżywaniu własnych skłonności i preferencji seksualnych. Zdania psychologów i psychiatrów są w tym względzie podzielone. Nie można jednak zaprzeczyć, że istnieją środowiska czy ośrodki niosące osobom zainteresowanym procesem przemiany pomoc w tym właśnie zakresie. Por. Chłopkowska, Wyzwolenie w Chrystusie, 67-92; Landwójtowicz, „Duszpasterska troska”, 101-115; Nicolosi - Nicolosi, Dziecko a skłonności, 279-322; Teisa, Le strade dell'amore, 212-289.

Por. Schuchts, „Przywrócić pełnię”, 58. 
nym z zamysłem Bożym: wiemy, że człowiek ulega słabościom, ale Parlament w ten sposób poparł ludzkie słabości" ${ }^{\text {} 4}$. Niestety w przeciągu kilku dekad liczne kraje uległy silnej presji środowisk homoseksualnych. W obliczu tych tendencji Magisterium Kościoła po raz kolejny przypomniało fundamenty katolickiego nauczania o małżeństwie i odwołując się do racjonalnych argumentów, oceniło podejmowane próby legalizacji związków jednopłciowych.

Opublikowany w 2003 r. przez Kongregację Nauki Wiary dokument Uwagi dotyczące projektów legalizacji prawnej związków między osobami homoseksualnymi nie przyniósł nowych elementów doktrynalnych. Jego celem było - na podstawie dotychczasowego nauczania Kościoła - wskazanie zwłaszcza politykom katolickim argumentów o charakterze racjonalnym, aby w działaniach legislacyjnych kierowali się prawym sumieniem ${ }^{85}$. Rozpatrując w perspektywie katolickiej ewentualne propozycje zrównania związków osób tej samej płci z małżeństwem, należy także pamiętać o zasadniczych tezach antropologii biblijnej, z którymi mogliśmy się zapoznać w pierwszej części niniejszego opracowania. Wynika z nich, że „nie istnieje żadna podstawa do porównywania czy zakładania analogii, nawet dalekiej, między związkami homoseksualnymi a planem Bożym dotyczącym małżeństwa i rodziny" ${ }^{\prime \prime}$. Przywołane w dokumencie argumenty biblijne są przygotowaniem dla podjęcia refleksji na płaszczyźnie ponadwyznaniowej. Odwołując się do racji rozumowych, Kongregacja ukazuje powody, dla których państwowy porządek prawny nie powinien ulegać presji środowisk domagających się legalizacji związków osób tej samej płci, a niekiedy ubiegających się także o adopcję dzieci. Argumentacja została przedstawiona na czterech płaszczyznach.

Pierwszą z nich jest płaszczyzna relacji prawa stanowionego do prawego rozumu. Stanowione w parlamentach prawo ma służyć dobru osoby i ludzkiej wspólnoty. Aby spełnić tę rolę, nie może być ono sprzeczne z naturalnym prawem moralnym, które jest źródłem norm podstawowych. Należą do nich m.in. prawo do życia czy ochrona małżeństwa mężczyzny i kobiety jako optymalnego środowiska narodzin i rozwoju człowieka ${ }^{87}$. Tę ostatnią zasadę w czytelny sposób przypomniał papież Franciszek: „jasna i dobrze określona obecność obu postaci, męskiej i żeńskiej, tworzy najbardziej właściwe środowisko dla dojrzewania dziecka"88. Z tego powodu państwo, legalizując związki homoseksualne, uchybiałoby swoim podstawowym zadaniom ochrony małżeństwa jako instytucji ważnej z punktu widzenia dobra wspólnego. Co więcej, legalizacja tego typu wpływałaby niekorzystnie na kształtowanie mentalności

\footnotetext{
84 Jan Paweł II, „Nie wolno fałszować”, 39.

85 Por. Kongregacja Nauki Wiary, Uwagi dotyczace projektów, nr 1.

86 Kongregacja Nauki Wiary, Uwagi dotyczace projektów, nr 4. Por. Franciszek, Amoris laetitia, nr 251.

87 Por. Międzynarodowa Komisja Teologiczna, W poszukiwaniu etyki, nr 49.

88 Franciszek, Amoris laetitia, nr 175.
} 
społecznej i obyczajów, co w dalszej perspektywie powodowałoby zamieszanie moralne i dewaluację małżeństwa ${ }^{89}$.

Druga płaszczyzna racjonalnego dowodzenia przeciw legalizacji związków homoseksualnych nawiązuje do antropologii z uwzględnieniem płciowego wymiaru ludzkiego życia. Kongregacja przypomina, że w relacjach jednopłciowych brakuje istotnych elementów konstytutywnych warunkujących prokreację i ciągłość pokoleń. W tym kontekście formułuje zasygnalizowany już wcześniej argument, że „brak dwubiegunowości płciowej stwarza przeszkody w normalnym rozwoju dzieci, ewentualnie włączonych w takie związki. Brakuje im doświadczenia macierzyństwa albo ojcostwa"90. W konsekwencji ewentualną adopcję przez pary jednopłciowe uznać należy za przejaw swoistej przemocy wobec dzieci, gdyż zostają na siłę włączone do środowisk niegwarantujących im optymalnych warunków rozwoju. Integralny bowiem rozwój osoby, w tym rozwój psychoseksualny dziecka, dokonuje się prawidłowo w relacji do matki i ojca ${ }^{91}$, w stabilnej rodzinie. $Z$ powyższych powodów adopcja przez pary jednopłciowe stanowi w opinii Magisterium Kościoła złamanie międzynarodowej konwencji ONZ na temat praw dzieci ${ }^{92}$, którym - jako najsłabszym i bezbronnym - należy się ochrona ze strony autentycznej rodziny i instytucji ją wspierających. Dziecko ma niezbywalne prawo do rodziny ${ }^{93}$.

Nie bez znaczenia jest także rozważenie problemu legalizacji związków homoseksualnych na płaszczyźnie porządku społecznego. Rodzina oparta na małżeństwie mężczyzny i kobiety stanowi fundament życia społecznego. Powinna być zatem otaczana najwyższą troską i pomocą ze strony państwa. Jeśli jednak obok powyższego modelu zaistnieją inne równoprawne formy jednopłciowych związków, koncepcja małżeństwa ulegnie radykalnej zmianie, co nie pozostanie bez wpływu na rozumienie dobra wspólnego i funkcjonowanie społeczeństwa. Co stanie na przeszkodzie, aby za jakiś czas za małżeństwo uznać nie parę, ale na przykład trzy osoby? Nie można się w tej kwestii powoływać na prawo o niedyskryminacji osób o skłonnościach homoseksualnych. Odmowa możliwości zawarcia przez nie związku małżeńskiego nie narusza zasady sprawiedliwości. Wręcz przeciwnie, jest jej potwierdzeniem, gdyż wskazuje, że nie można nazywać małżeństwem tych form życia, którym brakuje konstytutywnych elementów małżeństwa. Pogląd ten nie jest dyskryminujący również i z tego powodu, że osoby o skłonnościach homoseksualnych mogą bez żadnych przeszkód realizować w sferze prywatnej to, co uważają za słuszne (na zasadach ogólnie przyjętych w dziedzinie swobód obywa-

89 Por. Kongregacja Nauki Wiary, Uwagi dotyczace projektów, nr 6.

90 Kongregacja Nauki Wiary, Uwagi dotyczące projektów, nr 7.

91 Interesujące studium $\mathrm{w}$ tym względzie, zawierające porównanie procesów wychowawczych w rodzinach opartych na heteroseksualnym małżeństwie i w związkach jednopłciowych, przedstawia Cezary Opalach („Rodzina wobec adopcji”, 141-156). Por. także: Nicolosi - Nicolosi, Dziecko a skłonności, 106-138.

93 Por. Fagan, „Niezbywalne prawo”, 239-249 
telskich). Czym innym jest jednak sfera publiczna, w której uwzględnić należy, czy poszczególne działania lub sposoby życia wnoszą wyraźnie pozytywny wkład na rzecz dobra wspólnego, aby promować je i premiować w postaci przywilejów społecznych. Należy zauważyć, że „związki homoseksualne nie realizują - nawet w najdalej idącej analogii - zadań, ze względu na które małżeństwo i rodzina zasługują na właściwe i specyficzne uznanie prawne" ${ }^{\prime 94}$.

Ostatnia płaszczyzna argumentacji zwraca uwagę na doniosłość instytucji małżeństwa w porządku prawnym. Zastanawiając się nad legalizacją związków homoseksualnych, należy zapytać, na ile przyczyniają się one do rozwoju dobra publicznego, aby proporcjonalnie do tego wkładu, mogły cieszyć się przywilejami nadawanymi przez wspólnotę. Ułatwienia i różnego rodzaju ulgi, jakie przysługują małżeństwu i rodzinie, nie wynikają $\mathrm{z}$ abstrakcyjnie pojmowanej zasady równości obywateli wobec prawa, ale są wyrazem uznania dla konkretnego dobra, jakie instytucje te przysparzają całemu społeczeństwu (prokreacja, wychowanie, ciągłość pokoleń). Mając to na względzie, Kongregacja Nauki Wiary ocenia - z zachowaniem należytego szacunku wobec konkretnych osób - że związki jednopłciowe „nie wymagają szczególnej uwagi ze strony ustawodawstwa prawnego, ponieważ nie odgrywają wspomnianej roli dla dobra wspólnego" ${ }^{\prime 5}$. Konkluzja ta wynika z zastosowania podstawowej zasady sprawiedliwości, według której słuszność moralna każe różnicować udział w przywilejach w zależności od stopnia wkładu w dobro wspólne. Sprawiedliwie nie zawsze oznacza równo. Jednocześnie należy pamiętać, że osoby o skłonnościach homoseksualnych cieszą się pełnią powszechnych praw osobistych i mogą odwołać się ,jak wszyscy obywatele na podstawie swej prywatnej autonomii do powszechnego prawa do ochrony sytuacji prawnych wspólnego interesu"96.

Mając na uwadze wyżej przytoczone racje, wszyscy katolicy, a zwłaszcza parlamentarzyści i inne osoby odpowiedzialne za stanowienie prawa, są moralnie zobowiązani do przeciwstawiania się prawnej legalizacji związków osób tej samej płci. W debacie publicznej należy odważnie podejmować to zagadnienie i odwołując się do argumentacji racjonalnej, wykazać sprzeczność zachodzącą pomiędzy żądaniami mniejszości seksualnych a integralnie pojętym dobrem osoby ludzkiej oraz społeczeństwa. Prawo cywilne powinno przede wszystkim stać na straży dobra wspólnego. Nie jest jego zadaniem zaspokajanie wszelkich roszczeń jednostek, zwłaszcza tych, co do których istnieją poważne przesłanki, że stanowią one zagrożenie ładu społecznego. Dlatego w przypadku, gdy po raz pierwszy ustawodawcy otrzymują pod obrady projekt przewidujący legalizację związków homoseksualnych, parlamentarzysta katolicki powinien - wyrażając czytelnie swój sprzeciw - odrzucić taki projekt. Ewentualne poparcie takiej propozycji należy uznać za czyn poważnie niemoralny. Z nieco

\footnotetext{
94 Por. Kongregacja Nauki Wiary, Uwagi dotyczace projektów, nr 8.

95 Kongregacja Nauki Wiary, Uwagi dotyczące projektów, nr 9.

96 Kongregacja Nauki Wiary, Uwagi dotyczące projektów, nr 9.
} 
inną sytuacją mamy do czynienia, gdy parlamentarzysta katolicki ma ustosunkować się do już funkcjonującego prawa przychylnego związkom jednopłciowym. Jeśli nie byłoby możliwe całkowite wyeliminowanie takiego ustawodawstwa, powinien on wyrażając otwarcie swój sprzeciw wobec niesprawiedliwego prawa - dążyć do ograniczenia szkodliwości takiej ustawy w przestrzeni moralności publicznej ${ }^{97}$. Oznacza to, zgodnie z nauczaniem encykliki Evangelium vitae, możliwość opowiedzenia się za prawem nie do końca satysfakcjonującym z katolickiego punktu widzenia, ale w danym momencie chroniącym w najpełniejszy sposób koncepcję małżeństwa i rodziny, jaką dyktuje prawy rozum ${ }^{98}$.

Katolicy żyjący we współczesnym świecie są świadomi, że ich spojrzenie na zjawisko homoseksualizmu kontrastuje z coraz powszechniejszą postawą społecznej akceptacji dla zachowań homoseksualnych. Wynika to nie tylko z postępującej sekularyzacji i osłabienia oddziaływania chrześcijaństwa na życie społeczne. Istotne znaczenie mają tu także trzy tendencje obecne w nowoczesnych społeczeństwach, które wpływają na styl myślenia i kształtowanie postaw, zwłaszcza najmłodszych pokoleń. Koniecznie należy je uwzględnić, chcąc prowadzić racjonalny dialog na temat moralnych aspektów homoseksualizmu.

Po pierwsze, coraz wyraźniej zaznacza się w życiu społecznym postmodernistyczne zwątpienie w istnienie obiektywnej prawdy. Zwłaszcza w naukach humanistycznych nie tylko pogłębia się kryzys prawdy, ale również sama rzeczywistość zaczyna tracić wiążący charakter. W myśl niektórych poglądów (np. teoria gender) ludzkie ciało nie ma normatywnego charakteru, a celowość wpisana w strukturę jego narządów nie wiąże w żaden sposób człowieka w ocenie zamiarów i podejmowaniu decyzji. Prowadzi to ostatecznie do wyrafinowanej formy irracjonalnej przemocy wobec ludzkiej natury. Mentalność tego typu popada jednak w wewnętrzną sprzeczność. Z jednej bowiem strony, wyzwolony z wszelkich ograniczeń egoistyczny antropocentryzm chce sam tworzyć sensy i znaczenia, a jednocześnie, gdy idzie o skłonności czy predyspozycje warunkujące pewne zachowania (np. homoseksualizm), utrzymuje się, że są one tak silnymi determinantami, że człowiek nie może nic z nimi zrobić, jak tylko im ulegać.

Drugą tendencją, którą należy uwzględnić w społecznej debacie dotyczącej moralnych aspektów zjawiska homoseksualizmu, jest zachwianie się w nowoczesnych demokracjach poprawnej korelacji pomiędzy dobrem osobistym a wspólnotowym. Wyraźnie zaznacza się prymat dobra indywidualnego, co w praktyce oznacza, że jednostki domagają się coraz więcej praw i przywilejów, nawet za cenę uszczerbku na dobru wspólnym. Jako najważniejsza jawi się zasada niedyskryminacji jednostek. Na dalszy plan schodzą pytania o dobro lub o ewentualne jego naruszenie, jakie nastąpi

97 Por. Kongregacja Nauki Wiary, Uwagi dotyczące projektów, nr 10.

98 Por. Jan Paweł II, Evangelium vitae, nr 73. 
we wspólnocie na skutek legalizacji związków homoseksualnych. Indywidualistycznie zorientowani obywatele coraz rzadziej stawiają sobie tego typu pytania.

Nie bez znaczenia jest wreszcie trzecie zjawisko, które należałoby uwzględnić w społecznej dyskusji o homoseksualizmie. Chodzi mianowicie o podstawowe pytanie, czy wolno od człowieka wymagać, aby rozwijał się i zmagał ze słabościami, celem przekraczania siebie ku obranej pełni, jaką uznaje za godną człowieczeństwa. A może jakiekolwiek wspomnienie o wymaganiach, walce, podejmowanym nawróceniu czy terapii to już oznaki dyskryminacji i nietolerancji? Wydaje się, że w przestrzeni demokratycznej powinna być zagwarantowana możliwość swobodnego wyboru opinii na ten temat, przy jednoczesnym pielęgnowaniu świadomości, że zawsze korzystniejszym dla człowieka i ludzkiej społeczności jest rozwój niż stagnacja, pokonywanie słabości, aniżeli uleganie im. Tak bynajmniej od wieków kultura europejska pojmowała autentyczny humanizm.

\section{Zakończenie}

Posoborowe nauczanie Kościoła na temat homoseksualizmu nie jest sylabusem błędów i potępień. Wychodzi od zwiastowania Dobrej Nowiny: pozytywnego przekazu prawdy o człowieku stworzonym na obraz Boży i odkupionym przez Chrystusa. Boży zamysł dotyczący mężczyzny i kobiety odsłania ich powołanie do budowania życiodajnej wspólnoty osób. Ukazuje egzystencjalną prawdę o wzajemnej komplementarności płci, prowadzącej do małżeńskiej komunii na wzór miłości Chrystusa do Kościoła. W świetle orędzia biblijnego zjawisko homoseksualizmu jawi się jako rezultat odwrócenia się człowieka od Boga, które prowadzi do przeżywania ludzkiej seksualności niezgodnie z mądrością i miłością Stwórcy. Dlatego skłonność homoseksualna jest obiektywnie nieuporządkowana, a czyny z niej wynikające i świadomie wybierane mają charakter zła moralnego. Od tak sformułowanej oceny skłonności i czynów trzeba jednak wyraźnie odróżnić sposób podejścia do osoby doświadczającej problemu homoseksualizmu. Należy się jej bezwzględny szacunek i duszpasterska troska. Postawa Kościoła katolickiego wiernie naśladuje w tym względzie samego Chrystusa, który piętnując grzech, z miłością odnosił się do upadających, podnosił ich i dawał nadzieję. Oznajmiał tym samym, że odnowiona przyjaźń z Bogiem dodaje sił, aby człowiek odzyskał panowanie nad swoim życiem i układał je w zgodzie z Bożą mądrością i miłością, co przyniesie pozytywne owoce w wymiarze osobistym i społecznym. 


\section{BIBLIOGRAFIA}

\section{Magisterium Kościoła}

a) Nauczanie soborowe

Sobór Watykański II, Gaudium et spes (1965).

\section{b) Dokumenty i wystąpienia papieskie}

Jan Paweł II, Encyklika Redemptor hominis (1979).

Jan Paweł II, Adhortacja apostolska Familiaris consortio (1981).

Jan Paweł II, Encyklika Veritatis splendor (1993).

Jan Paweł II, List do rodzin (1994).

Jan Paweł II, „Nie wolno fałszować norm moralnych. Rozważanie przed modlitwą Anioł Pański” (20 II 1994).

Jan Paweł II, E Evangelium vitae (1995).

Jan Paweł II, „Ojcostwo i macierzyństwo w zamyśle Bożym. Przemówienie do uczestników Tygodnia Studiów nad Małżeństwem i Rodziną” (27 VIII 1999).

Franciszek, Encyklika Laudato si (2015).

Franciszek, Adhortacja apostolska Amoris laetitia (2016).

Franciszek, Adhortacja apostolska Christus vivit (2019).

\section{c) Dokumenty Kurii Rzymskiej}

Kongregacja Nauki Wiary, Persona humana. Deklaracja o niektórych zagadnieniach etyki seksualnej (1975).

Kongregacja ds. Wychowania Katolickiego, Wytyczne wychowawcze w odniesieniu do ludzkiej miłości (1983).

Kongregacja Nauki Wiary, Homosexualitas problema. List do biskupów Kościoła katolickiego o duszpasterstwie osób homoseksualnych (1986).

Papieska Rada ds. Rodziny, Ludzka płciowość: prawda i znaczenie. Wskazania dla wychowania w rodzinie (1995).

Kongregacja Nauki Wiary, Uwagi dotyczace projektów legalizacji prawnej związków między osobami homoseksualnymi (2003).

Kongregacja ds. Wychowania Katolickiego, Instrukcja dotycząca kryteriów rozeznawania powołania $w$ stosunku do osób $z$ tendencjami homoseksualnymi $w$ kontekście przyjmowania ich do seminariów i dopuszczania do święceń (2005).

Międzynarodowa Komisja Teologiczna, W poszukiwaniu etyki uniwersalnej: nowe spojrzenie na prawo naturalne (2009).

Congregazione per l'Educazione Cattolica (degli Istituti di Studi), Maschio e femmina li creò. Per una via di dialogo sulla questione del «gender» nelleducazione (2019).

Papieska Komisja Biblijna, Czym jest człowiek (Ps 8,5). Zarys antropologii biblijnej (2019).

Kongregacja Nauki Wiary, Responsum ad dubium Kongregacji Nauki Wiary odnośnie udzielania błogosławieństwa związkom osób tej samej płci (2021).

d) Inne dokumenty doktrynalne

Katechizm Kościoła Katolickiego (1992). 


\section{Opracowania}

Augustyn, J., „Homoseksualizm w oczach Kościoła”, Znak 11 (2007) 10-15.

Augustyn, J., „Zjawisko homoseksualizmu a wychowanie do życia kapłańskiego i zakonnego”, Homoseksualizm. Dokumenty Kościoła, opracowania, rozmowy, świadectwa (red. T. Huk) (Warszawa: Verbinum 2000) 132-162.

Chłopkowska, I. (red.), Wyzwolenie w Chrystusie jako zasada działań pastoralnych wobec osób o orientacji homoseksualnej (Krościenko: Instytut im. ks. Franciszka Blachnickiego 2000).

Chrostowski, W., „Ludzka cielesność jako obraz Boga”, Collectanea Theologica 70/4 (2000) 5-19.

Czyżewski, B., „ «Uczyńmy człowieka na nasz obraz, podobnego nam» (Rdz 1,26) w interpretacji ojców Kościoła”, Studia Gnesnensia 25 (2011) 113-126.

Fagan, P.E., „Niezbywalne prawo dziecka do rodziny” (tł. M. Turski), Rodzina wiosna dla Europy i świata. Wybór tekstów z IV Światowego Kongresu Rodzin, 11-13 maja, Warszawa 2007 (red. T. Mazan - K. Mazela - M. Walaszyk) (Łomianki: Fundacja „Pomoc Rodzinie” 2008) 239-249.

Kiernikowski, Z., Dwoje jednym ciałem w Chrystusie (Warszawa: Wydawnictwo Księży Marianów 2000).

Kieniewicz, P.H., „Homoseksualizm”, Płciowość ludzka w kontekście miłości. Przesłanie moralne Kościoła (red. J. Nagórny - M. Pokrywka) (Lublin: Wydawnictwo KUL 2007) 203-217.

Kupczak, J., Amoris laetitia. Konflikt interpretacji (Poznań: W drodze 2020).

Landwójtowicz, P., „Duszpasterska troska Kościoła katolickiego o osoby homoseksualne”, Miłość - Płciowość - Płodność (red. P. Morciniec) (Opole: Wydział Teologiczny UO 2007) 101-115.

McNeill, J., The Church and the Homosexual, wyd. 4 (Boston, MA: Beacon Press 1993).

Melina, L., „Criteri morali per la valutazione dell'omosessualità", Antropologia cristiana e omosessualità (red. M. Agnes) (Città del Vaticano: L’Osservatore Romano 2003) 103-110.

Melina, L., „Skłonność homoseksualna jako «obiektywne nieuporządkowanie». Refleksje antropologii teologicznej", Prawda i miłość. Towarzyszenie osobom o skłonnościach homoseksualnych (red. J.E. Smith - P. Check; tł. M. Sobolewska) (Pelplin: Bernardinum 2017) 151-164.

Mondin, B., L'uomo secondo il disegno di Dio. Trattato di antropologia teologica (Bologna: Edizioni Studio Domenicano 1992).

Nicolosi, J. - Nicolosi, L.A., Dziecko a skłonności homoseksualne. Poradnik dla rodziców (tł. A. Jetkowska) (Poznań: W drodze 2013).

Opalach, C., „Rodzina wobec adopcji dzieci przez pary homoseksualne w kontekście «gender mainstreaming»", Idea "gender" jako wyzwanie dla teologii, (red. A. Jucewicz - M. Machinek) (Olsztyn: Hosianum 2009) 141-156.

Orzeszyna, J., „Skłonności homoseksualne w aspekcie wychowania dziecka”, Antropologia teologicznomoralna. Koncepcje. Kontrowersje. Inspiracje (red. I. Mroczkowski - J.A. Sobkowiak) (Warszawa: UKSW 2008) 133-152.

Paszewski, A., „Przyczyny orientacji homoseksualnej - co wnoszą do wiedzy badania nad bliźniakami", Family Forum 6 (2016) 31-43.

Przeciszewski, M., „Papież Franciszek wobec osób LGBT+”, https://ekai.pl/papiez-franciszek-wobec-osob-lgbt/ [dostęp: 20.08.2019]. 


\section{MACIEJ OLCZYK}

Schuchts, B., „Przywrócić pełnię zdrowia w Chrystusie”, Prawda i miłość. Towarzyszenie osobom o skłonnościach homoseksualnych (red. J.E. Smith - P. Check; tł. M. Sobolewska) (Pelplin: Bernardinum 2017) 55-84.

Synowiec, J.S., Na początku. Pradzieje biblijne. Rdz 1,1-11,9, wyd. 2 (Kraków: Bratni Zew 1996). Teisa, S. Le strade dell'amore. Omosessualità e vita cristiana (Roma: Città Nuova 2002).

Witczyk, H., „ «Obraz Boży» w człowieku - źródło i cel działania moralnego”, Antropologia teologicznomoralna. Koncepcje. Kontrowersje. Inspiracje (red. I. Mroczkowski - J.A. Sobkowiak) (Warszawa: UKSW 2008) 19-37. 